\title{
PENGARUH PERCEIVED USEFULLNESS, PERCEIVED EASE OF USE TERHADAP BEHAVIORAL INTENTION TO USE DENGAN ATITTUDE TOWARDS USING SEBAGAI VARIABEL INTERVENING
}

\author{
(STUDI KASUS PADA GOPAY DIKOTA YOGYAKARTA)
}

\author{
Rena Eka Setyawati \\ Fakultas Ekonomi Universitas Sarjanawiyata Tamansiswa Yogyakarta \\ Email: renaeka_s@yahoo.com
}

\begin{abstract}
Intisari
Penelitian ini bertujuan untuk mengetahui (1) pengaruh perceived usefullness terhadap attitude towards using dan, (2) pengaruh perceived ease of use terhadap attitude towards using (3) pengaruh attitude towards using terhadap behavioral intention to use (4) pengaruh perceived usefullness terhadap behavioral intention to use (5) pengaruh perceived ease of use terhadap behavioral intention to use (6) pengaruh perceived usefulness dan perceived ease of use terhadap attitude towards using (7) pengaruh perceived usefulness dan perceived ease of use terhadap behavioral intention to use. Sampel dalam penelitian ini adalah 115 mahasiswa/mahasiswi Fakultas Ekonomi Universitas Sarjanawiyata Tamansiswa Yogyakarta pengguna GOPAY. Metode pengumpulan data menggunakan metode kuesioner yang di bagikan menggunakan teknik Accidental Purposive Sampling. Dalam penelitian ini digunakan uji kualitas data, uji asumsi klasik (uji normalitas, uji multikolinieritas, dan uji heterokesdastisitas), analisis regresi linier berganda dan uji hipotesis. Hasil peneltian menunjukkan bahwa variabel perceived usefullness bepengaruh terhadap attitude towards using, variabel perceived ease of use berpengaruh terhadap attitude towards using, variabel attitude towards using berpengaruh terhadap behavioral intention to use, variabel perceived usefullness berpengaruh terhadap behavioral intention to use, variabel perceived ease of use berpenaruh terhadap behavioral intention to use, variabel perceived usefulness dan perceived ease of use berpengaruh terhadap attitude towards using, variabel perceived usefulness dan perceived ease of use berengaruh terhadap behavioral intention to use.
\end{abstract}

Kata-kata Kunci : GOPAY, perceived usefulness, perceived ease of use, attitude towards using, behavioral intention

\section{Abstract}

This study aims to determine (1) the effect of perceived usefulness on attitude towards using and, (2) the effect of perceived ease of use on attitude towards using (3) the effect of attitude towards using on behavioral intention to use (4) the effect of perceived usefulness on behavioral intention to use (5) the effect of perceived ease of use on behavioral intention to use (6) the effect of perceived usefulness and perceived ease of use on attitude towards using (7) the effect of perceived usefulness and perceived ease of use on behavioral intention to use. The sample in this study were 115 students of the Faculty of Economics, University of Sarjanawiyata Tamansiswa Yogyakarta, users of GOPAY. The data collection method uses a questionnaire method that is distributed using the Accidental Purposive Sampling technique. In this research, data quality test, classical assumption test (normality test, multicollinearity test and heterokesdasticity test) are used, multiple linear regression analysis and hypothesis testing. The results of the study show that the perceived usefullness variable influences the attitude towards using, the perceived ease of use variable influences the attitude towards using, the attitude towards using variable influences the behavioral intention to use, the perceived usefullness variable influences the behavioral intention to use, 
the perceived ease of use variable influence on behavioral intention to use, the variable perceived usefulness and perceived ease of use influence the attitude towards using, the variable perceived usefulness and perceived ease of use affect the behavioral intention to use. Keywords: GOPAY, perceived usefulness, perceived ease of use, attitude towards using, behavioral intention to use.

\section{PENDAHULUAN}

Kemajuan zaman menuntut perkembangan teknologi dan informasi di masyarakat, termasuk dalam bidang ekonomi dimana masyarakat dituntut untuk menyesuaikan diri dengan sistem teknologi dan informasi yang semakin berkembang. Perkembangan tekologi ini sejalan dengan kemudahan di segala aspek kehidupan masyarakat dengan bantuan online sistem. Pemanfaatan online sistem (e-commerce) ini meliputi kemudahan jual beli dengan marketplace, e-banking, e-wallet dan fintech. Produk fintech dapat memberikan kemudahan pembayaran di era digital saat ini salah satunya adalah $e$-wallet. Dengan tersedianya alat pembayaran non tunai salah satunya $e$-wallet dalam suatu sitem pembayaran maka akan dapat mengoptimalkan daya beli di masyarakat yang sekaligus akan berdampak pada meningkatnya perekonomian negara (Abidin, 2015). GO-PAY adalah salah satu contoh dari $e$-wallet.

Go-Pay merupakan prduk layanan yang dikeluarkan oleh PT DAB yang terdaftar dan dipantau oleh Bank Indonesia, yang memiliki fungsi yang sama dengan uang tunai yang dapat digunakan sebagai uang tunai atau instrumen pembayaran yang sah. Go-Pay merupakan layanan yang memfasilitasi pembayaran transaksi antara konsumen dan pelaku bisnis. Pada tahun 2017 Gojek dianugerahi penghargaan dari Bank Indonesia dan masuk dalam kategori Perusahaan Fintech Teraktif Pendukung Gerakan Nasional Non Tunai (GNNT) Inklusi dan Edukasi Keuangan serta Pemberdayaan UMKM. Berdasakan keterangan resmi dari Fortune pada tahun 2018, total pembelian produk dan penggunaan jasa dengan menggunakan go - pay sebagai alat pembayaran telah mencapai lebih dari US \$ 6 miliar atau setara dengan 85 triliun rupiah. Dan pada tahun 2019 ini Gojek menjadi satu - satunya perusahaan asal Indonesia yang menerima penghargaan dalam Fortune's "Change the World" karena memiliki kinerja dan memiliki dampak positif yang bermanfaat, berguna dan menguntungkan untuk masyarakat luas khususnya di Indonesia. Perceived Usefulness dapat diartikan bahwa "the degree to which a person believes that using a particular system would enhance his or her job performance" hal tersebut berarti bahwa persepsi manfaat merupakan suatu langkah dimana pengguna yakin bahwa menggunakan suatu sistem teknologi bisa meningkatkan kinerja maupun prestasi kerja seseorang (Davis, 1989). Persepsi kemudahan adalah persepsi seseorang tentang kemudahan dalam menggunakan suatu sistem teknologi. Pengguna merasa bahwa suatu sistem mudah digunakan jika pegguna tersebut merasa dia tidak kesulitan dalam menggunakan sistem tersebut (Nurmalia \& Wijayanti, 2018).

Attitude Towards Use dikonsepkan sebagai suatu sikap seseorang yang berbentuk penerimaan atau penolakan terhadap penggunaan suatu sistem tekologi guna untuk pemenuhan berbagai kegiatan dalam pekerjaannya (Widodo \& Azdy P., 2017). Behavioral Intention merupakan suatu niat, keinginan atau minat seseorang untuk melakuan suatu tindakan atau perilaku tertentu, seseorang akan melakukan suatu tindakan atau perilaku tertentu jika seseorang tersebut memiliki keinginan dan minat untuk melakukannya. Selain itu minat juga dapat diindikasikan bahwa akan dilakukannya suatu perilau atau tindakan tertentu dimasa depan atau di waktu yang akan datang dan mengulangnya dikemudian hari (Aditya \& Wardhana, 2016). 
Dengan adanya fenomena-fenomea diatas peneliti bermaksud untuk melakukan penelitian dengan obyek penelitian adalah penggunaan Go-Pay sebagai alat transaksi pembayaran layanan Go-Jek di kota Yogyakarta. Adapun judul penelitian yang akan diangkat adalah "PENGARUH PERCEIVED USEFULLNES, PERCEIVED EASE OF USE TERHADAP BEHAVIORAL INTENTION MELALUI ATTITUDE TOWARDS USE SEBAGAI VARIABEL INTERVENING".

\section{TINJAUAN PUSTAKA DAN PENGEMBANGAN HIPOTESIS Technologi Acceptance Model}

Konsep Technology Acceptance Model yang sudah dikembangkan oleh Davis (1989), merupakan sebuah teori yang dapat digunakan untuk menjelaskan mengenai faktor-faktor yang dapat berpengaruh diterimanya suatu sistem serta mendeskripsikan bagaimana suatu sistem dapat diterima oleh pengguna dan digunakan oleh pengguna sistem dalam mendukung kegiatan sehari-harinya atau pekerjaannya (Novindra \& Rasmini, 2017).

\section{Perceived Usefulnes}

Davis (1989) mengemukakan bahwa "the degree to which a person believes that using a particular system would enhance his or her job performance." Hal diatas dimaksudkan jika pengguna mempercayai jika seseorang menggunakan suatu sistem teknologi tertentu, maka dapat meningatkan kinerja dan prestasi kerja dari pengguna sistem tersebut. Hal tersebut menggambarkan bahwa dalam suatu sistem tertentu terdapat manfaat yang saling berkaitan dengan berbagai aspek (Fatmawati, 2015). Indikator Perceived Usefulness menurut Jogiyanto (2008:152) yaitu: 1) Mempercepat Pekerjaan (Work More Quikly), 2) Kinerja Pekerjaan (Job Performance), 3) Menambah Produktifitas (Increase Productivity), 4) Efektifitas (Effectiveness), 5) Menjadikan Pekerjaan Lebih Mudah (Make Job Easier), 6) Bermanfat (Useful).

\section{Pereived Ease Of Use}

Disebutkan bahwa "ease" artinya "freedom from difficulty or great effort." Selanjutnya "ease to use perceived" didefinisikan "the degree to which a person believes that using a particular system would be free of effort" Davis (1989). Jika suatu sistem tersebut mudah dalam penggunaannnya maka tidak akan memerlukan usaha yang keras untuk menggunakannya, hal ini termasuk kedalam kemudahan penggunaan sistem. Indikator Perceived Ease Of Use: 1) Mudah untuk dipelajari (Easy to Learn), 2) Mudah untuk dioperasikan (Understandable), 3) Fleksibel (Flexibel), 4) Dapat dikontrol (Controllable), 5) Mudah untuk digunakan (Ease of Use).

\section{Attitude Toward Using}

Attitude Toward Using merupakan Sikap penggunaan teknologi dalam teori TAM yang dikonsepkan sebagai suatu sikap seseorang terhadap penggunaan suatu sistem tenologi yang dapat berbentuk penerimaan atau penolakan seseorang sebagai dampak apabila menggunakan suatu sistem teknologi dalam memenuhi kebutuhan pekerjaannya. Davis (1993) Sikap penggunaan teknologi didefinisikan Davis sebagai suatu perasaan positif atau negatif dari seseorang jika harus melakukan suatu tindakan terhadap suatu sistem. Schiffman and Kanuk (2008) dalam (Pratama \& Bastiaan, 2017) menjabarkan model sikap yang terdiri dari tiga indikator, yaitu : 1) Komponen Kognitif, 2) Komponen Afektif, 3) Komponen Konasi.

\section{Behavioral Intention To Use}

Behavioral intention atau minat perilaku merupakan suatu niat, keinginan (minat) sesorang untuk melakukan suatu tindakan atau perilaku tertentu. Seseorang dapat melakukan suatu perilaku atau tindakan tertentu jika memiliki niat, keinginan (minat) untuk melakukan perilaku tersebut. Minat juga dapat mengindikasikan adanya tindakan atau perilaku yang akan dilakukan dimasa yang akan datang dan akan mengulangnya di kemudian hari (Aditya \& 
Wardhana, 2016). Menurut Menurut Ferdinand (2011:129) minat dapat diidentifikasi melalui indikator yaitu: 1) Minat Transaksional, 2) Minat Preferensial, 3) Minat Referensial.

\section{PENGEMBANGAN HIPOTESIS}

\section{Pengaruh Perceived Usefulness terhadap Attitude}

Perceived Usefulness dapat mempengaruhi sikap seseorang dalam menerima suatu teknologi baru karena adanya peningkatan kinerja yang dihasilkan setelah penggunaan teknologi tersebut. Konsep ini juga menggambarkan manfaat sistem bagi pemakainya yang bekaitan dengan produktivitas, job perormance, efetivitas, dan kebermanfaatan secara keseluruhan, sehingga persepsi konsumen atas kegunaan akan berdampak positif terhadap sikap kosumen. Beberapa penelitian terdahulu yang dilakukan oleh Sabili (Ma'ruf, 2018), (Oentario et al., 2017), (Widodo \& Azdy P., 2017), (Mulyani \& Kurniadi, 2015), (R. \& Rukhviyanti, 2015) menunjukkan adanya pengaruh positif dan signifikan dari variabel Perceived Usefulness terhadap Attitude konsumen. Berdasarkan penelitian - penelitian tersebut dapat dilihat bahwa varabel Perceived Usefulness dapat mempengaruhi Attitude.

H1 : Terdapat pengaruh positif dan signifikan antara Perceived Usefulness terhadap Attitude.

\section{Pengaruh Perceived Ease Of Use terhadap Attitude}

TAM menyatakan bahwa variabel Perceived Ease Of Use merupakan faktor penentu penting dari variabel Attitude. Konsep ini mengambarkan kemudahan sistem bagi penggunanya yang berkaitan dengan fleksibel, jelas dan dapat dipahami serta mudah digunakan secara keseluruhan, sehingga persepsi konsmen atas kemudahan akan berdampak positif terhaap sikap kosumen. Beberapa penelitian terdahulu yang dilakukan oleh (Ma'ruf, 2018), (Oentario et al., 2017), (Widodo \& Azdy P., 2017), (Mulyani \& Kurniadi, 2015), (R. \& Rukhviyanti, 2015), (Sidharta \& Sidh, 2014) menunjukkan adanya pengaruh positif dan signifikan dari variabel Perceived Ease Of Use terhadap Attitude konsumen. Berdasarkan penelitian - peneliian tersebut dapat dilihat bahwa varabel Perceived Ease Of Use dapat mempengaruhi Attitude.

H2 : Terdapat pengaruh positif dan signifikan antara Perceived Ease Of Use terhadap Attitude.

\section{Pengaruh Attitude terhadap Behavioral Intention To Use}

Persepsi sikap konsumen terhadap intensitas penggunaan sistem yang mampu meningkatkan kinerja penguna dapat mendorong psikologis pengguna tersebut untuk menerima penggunaan teknologi dalam pekejaannya. Beberapa penelitian terdahulu yang dilakukan oleh (Oentario et al., 2017), (Chitra Laksmi Rithmaya, 2016), (R. \& Rukhviyanti, 2015), (Sidharta \& Sidh, 2014) menyatakan adanya pengaruh yang positif dan dignifikan dari variabel sikap konsumen terhadap minat bertransaksi secara online. Berdasarkan penelitian peneltian tersebut dapat dilihat bahwa vaiabel Attitude dapat mempengaruhi Behavioral Intention To Use.

H3 : Terdapat pengaruh positif dan signifikan dari persepsi kegunaan Attitude terhap sikap pengunaan Behavioral Intention To Use.

\section{Pengaruh Perceived Usefulness terhadap Behavioral Intention To Use}

Perceived Usefulness dapat mempengaruhi intensitas penggunaan teknologi. Dengan meningkatnya penggunaan teknologi maka terdapat manfaat, manfaat yang dirasakan oleh pengguna mampu meningkatkan minat untuk menggunakan. Penelitian - penelitian tersebut dapat dilihat bahwa variabel Perceived Usefulness dapat mempengaruhi Behavioral Intention To Use. Beberapa penelitian terdahulu yang dilakukan oleh (Fadlan, 2018), (Aditya \& 
Wardhana, 2016), (Chitra Laksmi Rithmaya, 2016), (Wahyuningtyas, 2016), (Wibowo \& Rosmauli, 2015) menunjukkan bahwa variabel persepsi kegunaan memiliki pengaruh positif dan signifikan terhadap Behavioral Intention To Use. Berdasarkan penelitian - penelitian tersebut dapat dilihat bahwa variabel Perceived Usefulness dapat mempengaruhi Behavioral Intention To Use.

H4 : terdapat pengaruh positif dan signifikan antara Perceived Usefulness terhap Behavioral Intention To Use.

\section{Pengaruh Perceived Ease Of Use terhadap Behavioral Intention To Use}

Adanya kemudahan yang dirasakan oleh pengguna teknologi akan meningkatkan minat mereka untuk menggunakan teknologi. Konsumen menginginkan kemudahan dari aktivitas transaksi yang dilakukannya. Beberapa penelitian terdahulu yang dilakukan oleh (Fadlan, 2018), (Aditya \& Wardhana, 2016), (Chitra Laksmi Rithmaya, 2016), (Wahyuningtyas, 2016), (Wibowo \& Rosmauli, 2015) menunjukkan bahwa variabel persepsi kegunaan memiliki pengaruh positif dan signifikan terhadap minat bertransaksi secara online.

H5 : Perceived Ease Of Use berpengaruh positif dan signifikan terhadap Behavioral Intention.

\section{Pengaruh secara bersama - sama Perceived Usefullness dan Perceived Ease Of Use terhadap Attitude.}

Sikap pengunaan dalam TAM dikonsepkan sebagai suatu sikap terhadap penggunan sistem yang berentuk penerimaan atau penolakan terhadap sistem tersebut. Menurut TAM, sikap penggunaan teknologi ditentukan oleh Perceived Usefulness dan Perceived Ease OfUse. Temuan ini sejalan dengan penelitian terdahulu yang dilakukan oleh (Widodo \& Azdy P., 2017) yang menunjukkan bahwa Perceived Usefullness dan Perceived Ease Of Use berpengaruh positif dan signfikan terhadap Attitude.

H6 : Perceived Usefuness dan Perceived Ease Of Use berpengaruh positif dan signifikan terhadap Atiitde Toward Using.

\section{Pengaruh secara bersama - sama Perceived Usefullness dan Perceived Ease Of Use terhadap Intention To Use.}

Perceived Usefullness berpengaruh secara langsung maupun tidak langsung terhadap Behavioral Intention, selain itu Perceived Ease Of Use juga berpengaruh terhadap Minat Penggunaan Ulang baik secara langsung maupun tidak langsung. Kedua faktor tersebut merupakan faktor pendorong adanya Behavioral Intention atau Minat penggunaan ulang pada suatu teknologi. Jika pengguna merasakan adanya kemudahan dan manfaat terhadap sistem maka Minat Penggunaan Ulang terhadap sistem tersebutakan semakin tinggi. Beberapa penelitian terdahulu yang dilakukan oleh (Aditya \& Wardhana, 2016), (Fadlan, 2018) yang menunjukkan bahwa adanya pengaruh dari Perceived Usefulness dan Perceived Ease Of Use Terhadap Behavioral Intention, selain itu temuan ini juga sejalan dengan Technology Acceptance Model yang dikemukakan oleh Davis (1989) yang menyatakan bahwa Percieved Ease of Use dan Percieved Usefulness sebagai bagian dari penentu utama perilaku, yang dalam penelitian ini disebutkan sebagai Penggunaan Mobile Banking.

H7 : Perceived Usefuness dan Perceived Ease Of Use berpengaruh positif dan signifikan terhadap Behavioral Intention.

\section{METODE PENELITIAN}

Metode penelitian yang akan digunakan atau dipakai dalam penelitian ini adalah metode penelitian kuantitatif. Metode penelitian yang akan digunakan adalah explanatory survey. Populasi dalam penelitian ini adalah para mahasiswa yang pernah menggunakan go - pay 
dikota Yogyakarta. Populasi dalam penelitian ini memiliki sifat tidak terbatas, dimana jumlah dan karakteristik dari responden penelitian tidak diketahui secara pasti. Responden penelitian ini adalah semua mahasiswa yang pernah menggunakan go - pay. Alasan melakukan penelitian ini di Jogja yaitu karena penelitian ini lebih berfokus terhadap Intensitas penggunaan go - pay di kota YogyakartA.

Sampel pada penelitian ini yaitu mahasiswa Fakultas Ekonomi Universitas Sarjanawiyata Tamansiswa yang menggunakan go - pay. Penentuan jumlah sampel ditentukan dengan menggunakan beberapa metode antara lain dengan menggunakan rumus rao purba sebagai berikut Widiyanto (2008). Apabila populasi berukuran besar dan jumlahya tidak diketahui maka digunakan rumus :

$$
\begin{aligned}
n & =\frac{\mathrm{Z}^{2}}{4(\mathrm{Moe})^{2}}=n=\frac{1,96^{2}}{4(0,1)^{2}} \\
& =\frac{3,8416}{0,04}=96,04 \\
& =96(\text { atau dibulatkan 100) }
\end{aligned}
$$

Dari hasil perhitungan sampel diatas maka jumlah sampel dalam penelitian ini sebanyak 100 responden. Untuk mengantisipasi adanya kesalahan dan kuesioner rusak atau tidak kembali maka digenapkan menjadi 115 sampel.

Teknik pengambilan sampel dalam penelitian ini dilakukan dengan mengunakan teknik non probability sampling karena besarnya peluang elemen untuk terpilih sebagai objek sampel tidak diketahui.Teknik pengambilan sampel dalam penelitian ini dilakukan dengan menggunakan (accidental purposive sampling), yaitu teknik penentuan sampel dengan pertimbangan tertentu. Pengambilan sampel yang dilakukan berdasarkan pertimbangan yang sesuai dengan maksud peneliti, dan bedasarkan spontanitas.

Pada penelitian ini digunakan jenis data primer berupa kuesioner yang diberikan kepada responden. Sumber data primer kuisioner berasal dari mahasiswa FE UST pengguna go - pay. Metode pengumpulan data dilakukan dengan cara menyebarkan kuisioner kepada responden melalui google form yang bersikan pertanyaan/pernyataan yang menyangkut seputar topik penelitian.

Analisis data pada penelitian ini terdiri dari analisis deskriptif, uj kualitas data (validitas, reliabiltas), uji asumsi klasik (uji normalitas, uji heterokedastisitas, dan uji multikolonieritas), uji regresi linier berganda, dan uji hipotesis (uji parsial / uji t, dan uji signifikan simultan / uji F, koefisien determinasi), sobel test.. Teknik analisis data diolah menggunakan program SPSS.

\section{HASIL DAN PEMBAHASAN}

Hasil dar tabel 2 menyatakan bahwa menunjukkan bahwa dari 115 responden, berjenis kelamin laki-laki yaitu sebanyak 42 dan yang berjenis kelamin perempuan sebanyak 73 . Prodi Manajemen yaitu 74 orang, sedangkan Prodi Akuntansi 41 orang.

Tabel 2. Karakteristik Responden

\begin{tabular}{lcc}
\hline Kategori & Frekuensi & Prosentase \\
\hline Jenis Kelamin & & \\
\hline Laki-Laki & 42 & 36,5 \\
Perempuan & 73 & 63,5 \\
\hline Prodi & & \\
\hline Manajemen & 74 & 64,3 \\
Akuntansi & 41 & 35,7 \\
\hline
\end{tabular}


Hasil uji validitas (Tabel 3) menunjukkan nilai corrected item-total correlation> dari $r$ - table $(0,1832)$ atau valid. Pengujian menghasilkan $\mathrm{r}$ hitung Perceived Usfullness, Perceived Ease Of Use, Atiude Towards Using, dan Behaviral Intentionto use > 0,1832. Cronbach's Alpha Stand. Perceived Usefullness (0,870), Perceived Ease Of Use $(0,892)$, Atiude Towards Using (0,808), dan Behaviral Intentionto use $(0,876)>0,60$ atau instrumen reliabel.

Tabel 3. Uji Validitas dan Reliabilitas

\begin{tabular}{|c|c|c|c|c|c|c|c|}
\hline \multicolumn{2}{|c|}{$\begin{array}{l}\text { Perceived } \\
\text { Usefullness }\end{array}$} & \multicolumn{2}{|c|}{$\begin{array}{c}\text { Perceived Ease Of } \\
\text { Use }\end{array}$} & \multicolumn{2}{|c|}{ Atittude Towards Using } & \multicolumn{2}{|c|}{$\begin{array}{l}\text { Behavioral } \\
\text { Intention }\end{array}$} \\
\hline PU1 & 0,634 & PEOU1 & 0,598 & ATU1 & 0,548 & BI1 & 0,710 \\
\hline PU2 & 0,532 & PEOU2 & 0,656 & ATU2 & 0,557 & $\mathrm{BI} 2$ & 0,763 \\
\hline PU3 & 0,614 & PEOU3 & 0,694 & ATU3 & 0,593 & $\mathrm{BI} 3$ & 0,722 \\
\hline PU4 & 0,599 & PEOU4 & 0,635 & ATU4 & 0,577 & BI4 & 0,653 \\
\hline PU5 & 0,462 & PEOU5 & 0,580 & ATU5 & 0,574 & BI5 & 0,696 \\
\hline PU6 & 0,666 & PEOU6 & 0,591 & ATU6 & 0,549 & BI6 & 0,547 \\
\hline PU7 & 0,635 & PEOU7 & 0,589 & & & & \\
\hline PU8 & 0,606 & PEOU8 & 0602 & & & & \\
\hline PU9 & 0,637 & PEOU9 & 0,682 & & & & \\
\hline PU10 & 0,528 & PEO10 & 0,675 & & & & \\
\hline PU11 & 0,400 & & & & & & \\
\hline PU12 & 0,362 & & & & & & \\
\hline \multicolumn{8}{|c|}{ Cronbach's Alpha } \\
\hline \multicolumn{2}{|c|}{0,870} & \multicolumn{2}{|c|}{0,892} & \multicolumn{2}{|c|}{0,808} & \multicolumn{2}{|c|}{0,876} \\
\hline
\end{tabular}

Tabel 4 menunjukkan model regresi tidak mengalami multikolonieritas (tolerance $>0,10$ dan VIF < 10), tidak mengalami heteroskedastisitas (nilai sig. > 0,05) dan data terdistribusi normal (Kolmogorov-Smirnovtest memiliki asymp sig > 0,05). Dengan demikian ketiga model regresi memenuhi persyaratan untuk diuji regresi.

Tabel 4. Asumsi Klasik

\begin{tabular}{|c|c|c|c|c|c|c|}
\hline & \multicolumn{2}{|c|}{ Variabel } & \multirow{2}{*}{$\frac{\text { Normalitas }}{\text { Sig. }}$} & \multicolumn{2}{|c|}{ Multikolonieritas } & \multirow{2}{*}{$\begin{array}{c}\text { Heteroskedastisitas } \\
\text { Sig. (two tailed) }\end{array}$} \\
\hline & Bebas & Terikat & & Tol. & VIF & \\
\hline \multirow{2}{*}{1} & $\begin{array}{l}\text { Perceived } \\
\text { Usefullness }\end{array}$ & \multirow{2}{*}{$\begin{array}{c}\text { Attitude } \\
\text { Toward } \\
\text { Using }\end{array}$} & \multirow{2}{*}{0,445} & 0,500 & 1,999 & 0,568 \\
\hline & $\begin{array}{c}\text { Perceived Ease Of } \\
\text { Use }\end{array}$ & & & 0,500 & 1,999 & 0,415 \\
\hline \multirow{3}{*}{2} & $\begin{array}{c}\text { Perceived } \\
\text { Usefullness } \\
\end{array}$ & \multirow{3}{*}{$\begin{array}{l}\text { Behavioral } \\
\text { Intention }\end{array}$} & \multirow{3}{*}{0,128} & 0,468 & 2,138 & 0,099 \\
\hline & $\begin{array}{c}\text { Perceived Ease Of } \\
\text { Use }\end{array}$ & & & 0,328 & 3,053 & 0,505 \\
\hline & $\begin{array}{c}\text { Attitude Toward } \\
\text { Using }\end{array}$ & & & 0,366 & 2,735 & 0,299 \\
\hline
\end{tabular}

Berdasarkan tabel 5 dapat dilihat nilai dari koefisien deterinasi variabel bebas (Perceived Usefullness dan Perceived Ease Of Use) secara bersama-sama mempengaruhi variabel tidak bebas (Attitude Toward Using) sebesar 0,628 yang menunjukkan variabel bebas secara bersama-sama mempengaruhi variabel tidak bebas sebesar $62,8 \%$ sisanya $37,2 \%$ disebabkan oleh variabel lain diluar kedua variabel tersebut. variabel bebas (Perceived Usefullness, Perceived Ease Of Use dan Attitude Toward Using) secara bersama-sama mempengaruhi variabel tidak bebas (Behavioral Intention) sebesar 0,573 yang menunjukkan variabel bebas 
secara bersama-sama mempengaruhi variabel tidak bebas sebesar 57,3\% sisanya 42,7\% disebabkan oleh variabel lain diluar ketiga variabel tersebut.

Berdasarkan tabel 5 nilai dari sig pada $F$ huitung adalah 0,000 atau lebih kecil dari 0,05 sehingga dapat dikatakan bahwa Ho ditolak. Hal tersebut berarti bahwa variabel independen yang digunakan yaitu Perceived Usefullness (PU) dan Perceived Ease Of Use (PEOU) secara bersama-sama memiliki pengaruh terhadap variabel dependen Atittude Towards Using (ATU). Untuk nilai dari sig pada $\mathrm{F}$ huitung adalah 0,000 atau lebih kecil dari 0,05 sehingga dapat dikatakan bahwa Ho ditolak. Hal tersebut berarti bahwa variabel independen yang digunakan yaitu Perceived Usefullness (PU) dan Perceived Ease Of Use (PEOU), Atittude Towards Using (ATU) secara bersama-sama memiliki pengaruh terhadap variabel dependen Behavioral Intention (BI).

Tabel 5. Pengujian Hipotesis

\begin{tabular}{|c|c|c|c|c|c|c|c|c|}
\hline Hip. & \multicolumn{2}{|c|}{ Variabel } & \multirow{2}{*}{$\begin{array}{c}\text { Stand. Coeff. } \\
\text { Beta }\end{array}$} & \multirow[b]{2}{*}{$t$} & \multirow{2}{*}{ Sig. } & \multirow{2}{*}{$\begin{array}{c}\text { Koef. } \\
\text { Detr. } \\
\text { Adj. } R S q\end{array}$} & \multirow[t]{2}{*}{$\mathrm{F}$} & \multirow[t]{2}{*}{ Sig. } \\
\hline & Bebas & Terikat & & & & & & \\
\hline H1 & Perceived Usefullness & \multirow{2}{*}{$\begin{array}{l}\text { Attitude Toward } \\
\text { Using }\end{array}$} & 0.453 & 2,791 & 0.006 & \multirow[b]{2}{*}{0,628} & \multirow[t]{2}{*}{97,160} & \multirow[t]{2}{*}{$0.000^{\mathrm{a}}$} \\
\hline $\mathrm{H} 2$ & $\begin{array}{l}\text { Perceived Ease Of } \\
\text { Use }\end{array}$ & & 0.308 & 7,687 & 0.000 & & & \\
\hline H3 & Perceived Usefullness & \multirow{3}{*}{$\begin{array}{l}\text { Behavioral } \\
\text { Intention }\end{array}$} & -0.031 & 2,226 & 0.028 & \multirow{3}{*}{0,573} & 52,031 & \multirow[t]{3}{*}{$0.000^{\mathrm{a}}$} \\
\hline H4 & $\begin{array}{c}\text { Perceived Ease Of } \\
\text { Use }\end{array}$ & & 0.747 & 4,031 & 0.000 & & & \\
\hline $\mathrm{H} 5$ & $\begin{array}{l}\text { Attitude Toward } \\
\text { Using }\end{array}$ & & 0.197 & 2,052 & 0.043 & & & \\
\hline
\end{tabular}

Hasil pengujian hipotesis tabel 5 menunjukkan variabel Perceived Usefullness berpengaruh positif signifikan terhadap Atittude Towards Using. Hal ini dibuktikan dengan melihat hasil tingkat signifikansi $0,006<0,05$ dan t hitung 2,791 > 1,981. Dengan demikian hipotesis pertama yang menyatakan Perceived Usefullness berpenaruh positif dan signifikan terhadap Atittude Towards Using "Diterima". Variabel Perceived Ease Of Use berpengaruh positif signifikan terhadap Atittude Towards Using. Hal ini dibuktikan dengan melihat hasil tingkat signifikansi $0,000<0,05$ dan t hitung 7,687 $>1,981$. Dengan demikian hipotesis kedua yang menyatakan Perceived Ease Of Use berpenaruh positif dan signifikan terhadap Atittude Towards Using "Diterima". Variabel Perceived Usefullness berpengaruh positif dan signifikan terhadap Behavioral Intention. Hal ini dibuktikan dengan melihat hasil tingkat signifikansi $0,028<0,05$ dan thitung 2,226 > 1,981. Dengan demikian hipotesis ketiga yang menyatakan Perceived Usefullness berpenaruh positif daan signifikan terhadap Behavioral Intention "Diterima". Variabel Perceived Ease Of Use berpengaruh positif dan tidak signifikan terhadap Behavioral Intention. Hal ini dibuktikan dengan melihat hasil tingkat signifikansi $0,000<0,05$ dan t hitung 4,031 > 1,981. Dengan demikian hipotesis keempat yang menyatakan Perceived Ease Of Use berpenaruh positif dan signifikan terhadap Behavioral Intention "Diterima". Variabel Atittude Towards Using berpengaruh positif dan signifikan terhadap Behavioral Intention. Hal ini dibuktikan dengan melihat hasil tingkat signifikansi $0,043<0,05$ dan thitung 2,052 > 1,981. Dengan demikian hipotesis kelima yang menyatakan Atittude Towards Using berpenaruh positif dan signifikan terhadap Behavioral Intention "Diterima". 


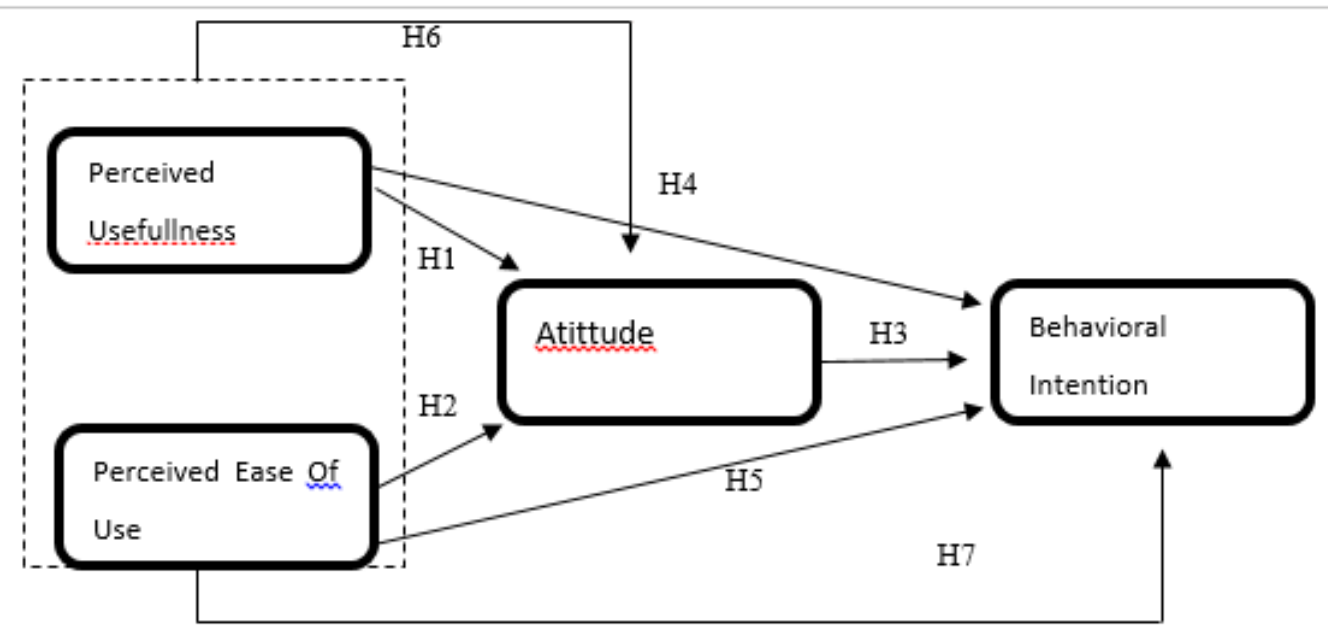

Gambar 1. Hasil Penelitian

Tahap I

Dari hasil uji sobel tes diatas diketahui one-tailed probability $0,04837660<0,05$. Maka dapat ditarik kesimpulan untuk variabel Atittude Towards Using bisa menjadi variabel intervening antara Perceived Usefullness dan Behavioral Intention. Serta membuktikan bahwa Perceived Usefullness berpengaruh terhadap Behavioral Intention melalui Atittude Towards Using "Diterima”..

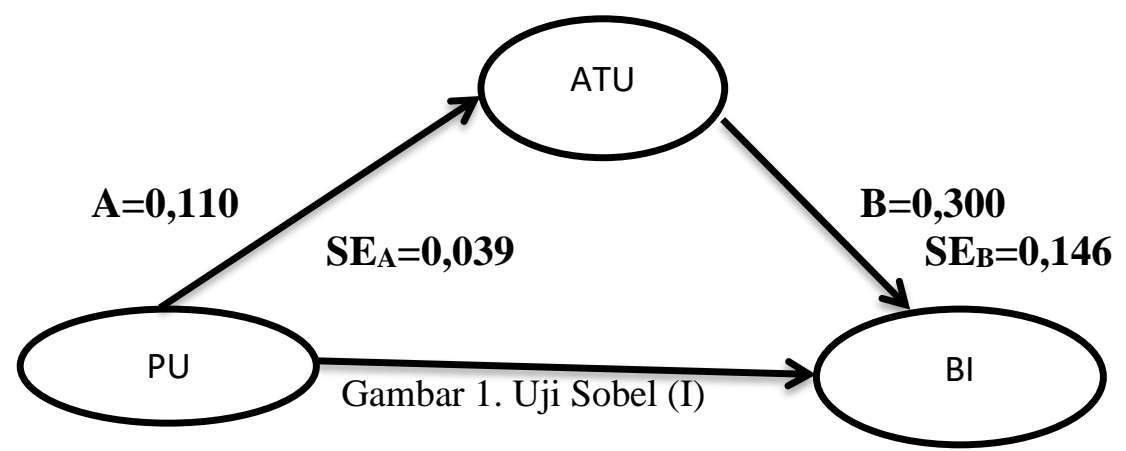

Dari hasil uji sobel tes diatas diketahui one-tailed probability $0,02354649<0,05$. Maka dapat ditarik kesimpulan untuk variabel Atittude Towards Using bisa menjadi variabel intervening antara Perceived Ease Of Use dan Behavioral Intention. Serta membuktikan bahwa Perceived Ease Of Use berpengaruh terhadap Behavioral Intention melalui Atittude Towards Using "Diterima".

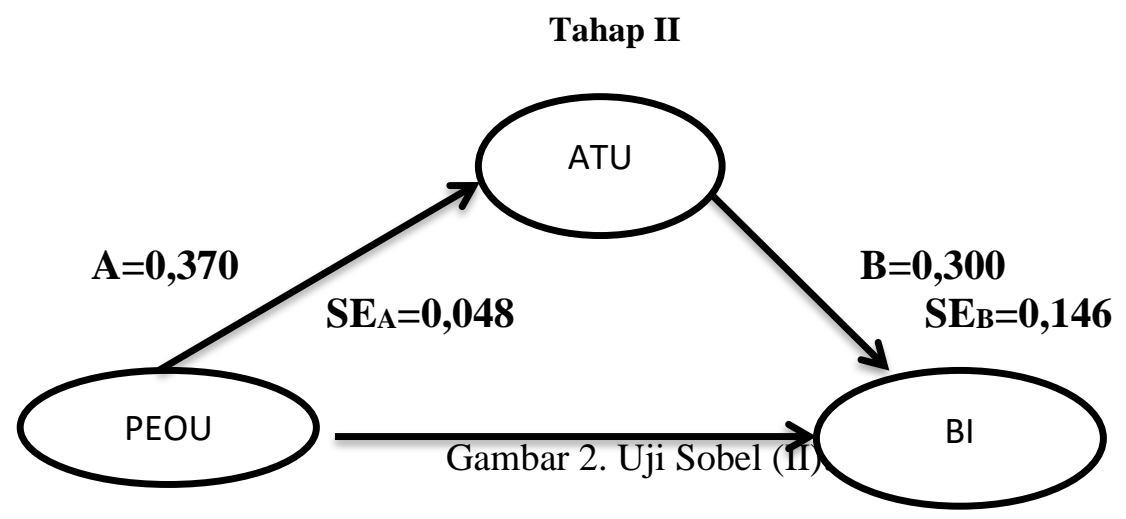




\section{PEMBAHASAN}

\section{Pengaruh Perceived Usefullness terhadap Atittude Towards Using}

Berdasarkan dari uji parsial ( $\mathrm{t}$ hitung) menunjukan bahwa varabel Perceived Usefullness berpengaruh positif secara signifikan terhadap variabel Atittude Towards Using. Berdasarkan hasil uji diatas menunjukkan bahwa penilaian tertinggi pada variabel Perceived Usefullness terjadi pada pernyataan menggunakan gopay membantu memudahkan saya dalam melakukan transaksi atau pembayaran. Dengan adanya manfaat yang ditawarkan pada sistem gopay yaitu dengan menggunakan gopay dapat mempermudah dalam melakukan transaksi dan pembayaran yang dilakukan sehingga hal itu membuat pengguna percaya bahwa menggunakan gopay merupakan ide yang baik dalam sistem pembayaran gojek. Berdasarkan penelitian diatas dapat disimpulkan bahwa Perceived Usefullness berpengaruh positif dan signifikan terhadap Atittude Towards Using

\section{Pengaruh Perceived Ease Of Use terhadap Atittude Towards Using}

Berdasarkan dari uji parsial (t hitung) menunjukan bahwa variabel Perceived Ease Of Use berpengaruh positif secara signifikan terhadap variabel Atittude Towards Using. Berdasarkan hasil uji diatas menunjukkan bahwa penilaian tertinggi pada variabel Perceived Ease Of Use terjadi pada pernyataan menggunakan go - pay dapat dilakukan kapan saja. Dengan adanya kemudahan sistem pembayaran gopay yang dapat digunakan kapan saja oleh pengguna tanpa terhalang waktu, hal tersebut membuat pengguna percaya bahwa dengan menggunakan gopay merupakan ide yang baik dalam sistem pembayaran gojek. Berdasarkan penelitian diatas dapat disimpulkan bahwa Perceived Usefullness berpengaruh positif dan signifkan terhadap Atittude Towards Using

\section{Pengaruh Atittude Towards Using terhadap Behavioral Intention}

Berdasarkan dari uji parsial (t hitung) menunjukan bahwa variabel Atittude Towards Using berpengaruh positif secara signifikan terhadap variabel Behavioral Intention. Berdasarkan hasil uji diatas menunjukkan bahwa penilaian tertinggi pada variabel Atittude Towards Using terjadi pada Pernyataan menggunakan gopay merupakan ide yang baik dalam sistem pembayaran gojek, dengan adanya persepsi pengguna tentang penggunaan sistem pembayaran dalam gojek dengan menggunakan gopay merupakan ide yang baik hal tersebut membuat pengguna berniat untuk terus menggunakan go-pay. Berdasaran penelitian diatas dapat disimpulkan bahwa Perceived Usefullness terhadap Atittude Towards Using

\section{Pengaruh Perceived Usefullness terhadap Behavioral Intention}

Berdasarkan dari uji parsial ( $\mathrm{t}$ hitung) menunjukan bahwa varabel Perceived Usefullness berpengaruh positif secara signifikan terhadap variabel Behavioral Intention. Berdasarkan hasil uji diatas menunjukkan bahwa penilaian tertinggi pada variabel Perceived Usefullness terjadi pada Pernyataan menggunakan gopay membantu memudahkan saya dalam melakukan transaksi atau pembayaran, dengan adanya manfaat dari sistem pembayaran gopay yaitu membantu memudahkan pengguna dalam melakukan transaksi atau pembayaran hal tersebut membuat pengguna berniat untuk terus menggunakan go-pay. Berdasarkan penelitan diatas dapat disimpulkan bahwa Perceived Usefullness terhadap Behavioral Intention.

\section{Pengaruh Perceived Ease Of Use terhadap Behavioral Intention}

Berdasarkan dari uji parsial (t hitung) menunjukan bahwa varabel Perceived Ease Of Use berpengaruh positif secara signifikan terhadap variabel Behavioral Intention. 
Berdasarkan hasil uji diatas menunjukkan bahwa penilain tertinggi pada variabel Perceived Ease Of Use terjadi pada Pernyataan menggunakan go - pay dapat dilakukan kapan saja. Dengan adanya kemudahan sistem pembayaran gopay yang dapat digunakan kapan saja oleh pengguna tanpa terhalang waktu, hal tersebut membuat pengguna berniat untuk terus menggunakan go-pay. Berdasarkan penelitan diatas dapat disimpulkan bahwa Perceived Ease Of Use terhadap Behavioral Intention.

\section{Pengaruh Perceived Usefullness dan Perceived Ease Of Use terhadap Atittude Towards Using}

Berdasarkan dari uji parsial ( $\mathrm{t}$ hitung) menunjukan bahwa varabel Perceived Usefullness dan Perceived Ease Of Use berpengaruh positif secara signifikan terhadap variabel Atittude Towards Using. Berdasarkan hasil uji diatas menunjukkan bahwa penilaian tertinggi pada variabel Perceived Usefullness terjadi pada Pernyataan menggunakan gopay membantu memudahkan saya dalam melakukan transaksi atau pembayaran Untuk penilain tertinggi pada variabel Perceived Ease Of Use terjadi pada Pernyataan menggunakan go - pay dapat dilakukan kapan saja. Dengan adanya manfat dan kemudahan yang diberikan oleh sistem pembayaran gopay yaitu berupa manfaat bahwa dengan menggunakan sistem tersebut dapat membantu pengguna dalam melakukan transaksi atau pembayaran, dan untuk kemudahan yang diberikan yaitu berupa sistem pembayaran gopay tersebut dapat dilakukan kapan saja, hal tersebut membuat pengguna percaya bahwa menggunakan gopay merupakan ide yang baik dalam sistem pembayaran gojek. Berdasarkan penelitian diatas dapat disimpulkan bahwa Perceived Usefullness dan Perceived Ease Of Use berpengaruh positif dan signifikan terhadap Atittude Towards Using.

\section{Pengaruh Perceived Usefullness dan Perceived Ease Of Use terhadap Behavioral Intention}

Berdasarkan dari uji parsial (t hitung menunjukan bahwa varabel Perceived Usefullness dan Perceived Ease Of Use berpengaruh positif secara signifikan terhadap variabel Behavioral Intention. Berdasarkan hasil uji diatas menunjukkan bahwa penilaian tertinggi pada variabel Perceived Usefullness terjadi pada Pernyataan menggunakan gopay membantu memudahkan saya dalam melakukan transaksi atau pembayaran Untuk penilain tertinggi pada variabel Perceived Ease Of Use terjadi pada Pernyataan menggunakan go - pay dapat dilakukan kapan saja. Dengan adanya manfat dan kemudahan yang diberikan oleh sistem pembayaran gopay yaitu berupa manfaat bahwa dengan menggunakan sistem tersebut dapat membantu pengguna dalam melakukan transaksi atau pembayaran, dan untuk kemudahan yang diberikan yaitu berupa sistem pembayaran gopay tersebut dapat dilakukan kapan saja, hal tersebut membuat pengguna berniat untuk terus menggunakan sistem pembayaran go-pay. Berdasarkan penelitian diatas dapat disimpulkan bahwa dan Perceived Ease Of Use berpengaruh positif dan signifkan terhadap Behavioral Intention.

\section{KESIMPULAN}

Penelitian ini bertujuan untuk menguji pengaruh Perceived Usefullness, Perceived Ease Of Use terhadap Behavioral Intention melalui Atittude Towards Using sebagai variabel intervening. Variabel Perceived Usefullness berpengaruh positif dan signifikan terhadap variabel Atittude Towards Using. Variabel Perceived Ease Of Use berpengaruh positif dan signifikan terhadap variabel Atittude Towards Using. Variabel Atittude Towards Using berpengaruh positif dan signifikan terhadap variabel Behavioral Intention. Variabel Perceived Usefullness berpengaruh positif dan signifikan terhadap variabel Behavioral Intention. 
Variabel Perceived Ease Of Use berpengaruh positif dan signifikan terhadap variabel Behavioral Intention. Variabel Perceived Usefullness dan variabel Perceived Ease Of Use berpengaruh positif dan signifikan terhadap variabel Atittude Towards Using. Variabel Perceived Usefullness dan variabel Perceived Ease Of Use berpengaruh positif dan signifikan terhadap variabel Behavioral Intention. Variabel Perceived Usefullness mampu mempengaruhi Behavioral Intention melalui Atittude Towards Using. Variabel Perceived Perceived Ease Of Use mampu mempengaruhi Behavioral Intention melalui Atittude Towards Using sebagai variabel intervening.

\section{Saran}

\section{Bagi Perusahaan}

Perusahaan gopay harus membuat sistemnya lebih fleksibel supaya pengguna dalam menggunakan sistem pembayaran tersebut dapat melakukan beberapa pekerjaan sekaigus dalam satu waktu. Perusahaan gopay harus meningkatkan iklan dan berbagai macam informasi, edukasi, serta sosialisasi tentang penggunaan sistem pembaran tersebut supaya pengguna dapat dengan mudah memahami informasi tentang sistem pembayaran gopay. Perusahaan harus lebih meningkatkan sistem keamanan yang ada di dalam sistem pebayaran gopay seperti contoh adanya riwayat transaksi. Dengan adanya sistem keamanan yang terjamin akan membuat pengguna merasa yakin dan aman dalam menggunakan sistem pembayaran gopay tersebut. Memberikan banyak kemudahan cara pembayaran dan sistem top up dalam gopay supaya pengguna memilih menggunakan gopay dari pada menggunakan sistem pembayaran tunai.

\section{Bagi Akademik}

Dapat dijadikan sebagai bahan pemikiran, pertimbangan atau bahan referensi penelitian dan lain-lainnya dengan variabel Perceived Usefullness, Perceived Ease Of Use, Atittude Towards Using dan Behavioral Intention. Untuk peneliti selanjutnya dalam bidang yang sama diharapkan dapat mencari variabel-variabel lain selain variabel Perceived Usefullness, Perceived Ease Of Use, Atittude Towards Using dan Behavioral Intention.

\section{DAFTAR PUSTAKA}

Abidin, M. S. (2015). Dampak Kebijakan E-Money Di Indonesia Alat Sistem Pembayaran Baru. (11080694234), 1-21.

Aditya, R., \& Wardhana, A. (2016). Pengaruh Perceived Usefulness Dan Perceived Ease Of Use Terhadap Behavioral Intention Dengan Pendekatan Technology Acceptance Model (TAM) Pada Pengguna Instant Messaging LINE Di Indonesia. Jurnal Siasat Bisnis, 20(1), 24-32. https://doi.org/10.20885/jsb.vol20.iss1.art3

Chitra Laksmi Rithmaya. (2016). Pengaruh Kemudahan Penggunaan, Kemanfaatan, Sikap, Risiko Dan Fitur Layanan Terhadap Minat Ulang Nasabah Bank Bca Dalam Menggunakan Initernet Banking. JOURNAL of RESEARCH in ECONOMICS and MANAGEMENT, 16.

Fadlan, A. (2018). Pengaruh Persepsi Kemudahan Dan Persepsi Kegunaan Terhadap Penggunaan Mobile Banking ( Studi Pada Mahasiswa Pengguna Mobile Banking Universitas Brawijaya ). Jurnal Administrasi Bisnis (JAB), 62(1). 
Fatmawati, E. (2015). Technology Acceptance Model (Tam) Untuk Menganalisis Penerimaan Terhadap Sistem Informasi Perpustakaan. Jurnal Igra', 09 No.01(01), 1-13.

Ma'ruf, S. (2018). The Influence Of Ease Of Use, Usefulness, Perceived Risk, And Convenience On Consumer Attitude On Online Shopping (A Case Study Of Lazada.Com) Oleh. Jurnal Fakultas Ekonomi, (3), 535-549.

Nurmalia, V. D., \& Wijayanti, L. E. (2018). Pengaruh Persepsi Kemudahan dan Persepsi Kemanfaatan Terhadap Minat Beli Secara Online. Jrmb, 13(1), 69-76. Retrieved from http://e-journalfb.ukdw.ac.id/index.php/jrmb/article/view/305

Oentario, Y., Harianto, A., \& Irawati, J. (2017). Pengaruh Usefulness, Ease of Use, Risk Terhadap Intentionto Buy Onlinepatisserie Melalui Consumer Attitude Berbasis Media Sosial Di Surabaya. Jurnal Manajemen Pemasaran, 11(1), 26-31. https://doi.org/10.9744/pemasaran.11.1.26-31

Purwitasari, M., \& Pratomo, D. (2015). The Influence Of Perceived Usefulness And Perceived Ease Of Use On Actual System Usage (Charging Efficiency Spt) By Perception Taxpayer (Survey Against The Person Taxable On Service Office Pratama Bandung Cibeunying). E-Proceeding of Management :, 2(3), 3213-3220.

Sidharta, I., \& Sidh, R. (2014). Pengukuran Persepsi Manfaat Dan Persepsi Kemudahan Terhadap Sikap Serta Dampaknya Atas Penggunaan Ulang Online Shopphing Pada ECommerce Iwan. Jurnal Computech \& Bisnis, 8(2), 92-100.

Tirtana, I., \& Sari, S. P. (2014). Analisis Pengaruh Persepsi Kebermanfaatan, Persepsi Kemudahan Dan Kepercayaan Terhadap Penggunaan Mobile Banking. Seminar Nasional Dan Call For Paper, 25, 671-688.

Wahyuningtyas, R. A. (2016). Pengaruh Persepsi Kemudahan Terhadap Niat Beli Ulang Dengan Persepsi Kegunaan Sebagai Variabel Intervening (Studi Pada Pengguna Layanan Aplikasi Go-Jek Di Surabaya). Jurnal Ilmu Manajemen, 4, 1-10.

Wibowo, S. F., \& Rosmauli, D. (2015). Pengaruh Persepsi Manfaat, Persepsi Kemudahan, Fitur Layanan, Dan Kepercayaan Terhadap Minat Menggunakan E-Money Card (Studi Pada Pengguna Jasa Commuterline Di Jakarta) Setyo. Jurnal Riset Manajemen Sains Indonesia (JRMSI), Vol.6, 440-456.

Alimul Hidayat, A Aziz. 2007. Metode Penelitin Keperawatan dan Teknik Analisis Data. Jakarta: Salemba Medika.

Ghozali, Imam. 2011. "Aplikasi Analisis Multivariate Dengan Program SPSS". Semarang: Badan Penerbit Universitas Diponegoro.

Jogiyanto. 2008. Metodologi Penelitian Sistem Informasi. Yogyakarta: ANDI.

Schiffman dan Kanuk, 2008. Perilaku konsumen. Edisi 7. Jakarta: Indeks

Sugiyono. (2013). Metode Penelitian Pendidikan. Cetakan Ke-16, Penerbit Alfabeta. Bandung. 